\title{
CHRISTUSVERKONDIGING EN DIE OU TESTAMENT
}

'n Hermeneutiese verkenning. ${ }^{1}$ ).

Die feit dat die oudste gedrukte Suid-Afrikaanse preek in $\mathrm{Ou}$ Testamentiese perikoop tot teks het, is miskien tekenend daarvan dat die Ou Testament in die geskiedenis van die Suid-Afrikaanse Christendom 'n groot rol gespeel het. ${ }^{2}$ ). So is dit byvoorbeeld duidelik dat die gelofte wat onder leiding van Charl Celliers deur die Voortrekkers voor Bloedrivier afgelê is, veral aansluit by die opvattings oor geloftes wat in die $\mathrm{Ou}$ Testament te vind is. Wanneer Paul Kruger by sy ampsaanvaarding as staatspresident die volk toespreek, wemel sy rede van verwysings na en voorbeelde uit die Ou Testament. Wanneer die Nederlandse gemeenskap Koninginnedag vier of wanneer die Afrikaners Geloftedag vier, is die teks vir die prediking hoogswaarskynlik 'n Ou-Testamentiese. Die rede vir hierdie verskynsel is waarskynlik 'n Ou-Testamentiese. Die rede vir hierdie verskynsel is waarskynlik daarin te vind dat die Ou Testament weens sy besondere aandag aan die geskiedenis van Israel en aan die instellinge van die maatskappy hom by uitstek leen vir bewysvoeringe en tekskeuse by openbare geleenthede. Die tekskeuse het dan ook gewoonlik berus op analogie in situasie, en daar was weinig oog vir die karakter van die $\mathrm{Ou}$ Testament as ' $\mathrm{n}$ dokument wat in sigself voorlopig is, en van Israel as „die gemeente van die verwagting". Ook kan met stelligheid beweer word dat die historiese karakter van die Ou-Testamentiese Godsopenbaring en die gevolglike eis van ondersoek na die koherensie van die Bybelse uitsprake nie altyd aan die orde gekom het nie.

Dat die prediking uit die Ou Testament in die verlede dikwels Ou Testamentiese prediking gebly het, dit wil sê sonder volgehoue perspektief op Christus, moet onder andere daaraan gewyt word dat die Ou Testamentiese wetenskap van die agtiende en negentiende eeu onder impuls van vreemde invloede nagelaat het om die kerklike prediking te dien met die middele wat nodig was om hierdie perspektief te behou. Die histories kritiese benadering was verantwoordelik vir 'n wyer-wordende breuk tussen Ou en Nuwe Testament, tussen die Israel-van-die-verwagting en die Israelvan-die-vervulling. Terwyl die direkte invloede van die histories-kritiese wetenskap slegs in die gevalle Begeman, Colenso en du Plessis die kerklike vlak beroer het, het die indirckte invloed daarvan veel verder gestrek, nl. enersyds in 'n krampagtige vasklou aan die Skrifbeskouing van die ge-

1) Rede gohou ter geleentheid van die amptelike opening van die Teologiese Fakuiteit (Afd. A) van die Universiteit van Pretoria by die aanvang van die akademiese jaar, op 19 Februarie 1963.

2) Predikatie over Jesaia 45:1-8 gedaan ter gelegentheid dat zijn HoogWelgebore Gestrenge de Heor Baron Gustaaf Wilhelm van Imhof is aangesteld tot Hoog Edele Gowwerneur Generaal van Nederlands Indien en de onderhorige landen . . . . door Wilhelm van Gendt, Bediener des Goddelyken Woords te Stellenbosch . . . 10 Februarie 1743. 
reformeerde skolastiek, andersyds in 'n verwarde en rigtinglose Skrifverklaring wat vaste wetenskaplike grond ontbeer het, juis omdat die historieskritiese benadering die prediker dikwels tussen 'n oorweldigende magdom van historiese, godsd:enshistoriese, vormhistoriese en literêre besonderhede ingelei het sonder om hom te bekommer oor wat al hierdie besonderhede eintlik met die middelpunt van die Skrif, Christus, te doen het. Daar was wel ook altyd dié paar perikope wat in hulle opening na vore tot erkenning van hul messiaanse karakter gedwing het, sodat daar onder andere van 'n „Messiasverwagting" in die Ou Testament gepraat kon word, maar van 'n besef dat Christus middelpunt van die hele Skrif is, was weinig te bemerk. Met verbasende naïwiteit is selfs gepoog om deur middel van historieskritiese afskilling deur te dring na die suiwere Godswoord wat in die huidige gestalte van die Skrif onder etlike lae mensewoorde bedek lê.

Dit is egter nie die bedoeling om hier ' $\mathrm{n}$ sonderegister vir die histories' kritiese wetenskap an te lê nie. Trouens, as dit probeer sou word, sou ons ook moes ingaan op die ander sy van die saak, en dan onvermydelik tot die slotsom kom dat die histories-kritiese benadering 'n ononcbeerlike stadium in die wetenskaplike Bybelondersoek is en sal bly. Om met verby. gaan van die historiese kritiek terug te gaan na die reformatoriese Skrifuitleg is nie meer moontlik nie. Die laaste 30,40 jaar het egter wel die besef gebring dat dit uit is met die alleenheerskappy van die historiese kritiek, juis omdat dit alleen nie by magte was om die hermeneutiese probleem te belig nie.

Die probleem van die verband tussen $\mathrm{Ou}$ en Nuwe Testament het opnuut aan die orde gekom toe vanuit die sistematiese teologie die Ou Testamentiese wetenskap opnuut herinner is aan die vereiste waaraan die uitleg van die Skrif moet voldoen, nl. dat dit van Christus moet getuig. Met hierdie vereiste is die Ou Testamentiese wetenskap gedwing om weer voor te begin en te vra wat die Ou Testament dan nou eintlik is. Die antwoord van die godsdienshistorici lui: Die oorkonde van die godsdiens van Israel. Met hierdie antwoord word die probleem egter nie geraak nie. Dat die Ou Testament veel aan godsdienshistoriese materiaal lewer, sal niemand betwyfel nie, en ons sal daar genoeë mee moet neem dat die Ou Testament ook deur die godsdienshistorikus gehanteer sal word. So ook deur die Hebraikus, die literatuur-historikus, die sinagoge.

Wanneer die Heidelbergse Kategismus (Sondag VI) egter sê dat ons die Here Jesus Christus ken „uit die heilige Evangelie wat God Self eers in die Paradys geopenbaar het en daarna deur die heilige aartsvaders en profete laat verkondig en deur die offerandes en ander seremonies van die Wet vooraf laat afbeeld het en eintlik deur Sy eniggebore Seun vervul het", word daarmee drie dinge onder die aandag gebring, nl.

1) die eenheid van die Heilige Skrif as getuienis van Jesus Christus, 
2) die voorlopigheid van die Ou Testament as getuienis-dokument,

3) die historiese gang van die evangelie van die paradys af tot by die vervulling.

Hierdie siening van die Skrif is tegelyk belydenis op grond van die getuienis van die Skrif self, sodat die weë van die godsdienshistorikus en die kerkteoloog hier baie beslis uiteenloop, so ook dié van die sinagoge en die kerk. Dit sluit nie uit dat die teoloog wat as lid en dienaar van die kerk die wetenskap van die kanon as faktiese gegewenheid beoefen, tog nog die volle veld van die $\mathrm{Ou}$ Testamentiese wetenskap tesame met die hulpwetenskappe sal deurwaad nie. Elke gegewene wat die ontstaan, agtergrond en inhoud van die $\mathrm{Ou}$ Testament kan belig, sal noodwendig bygehaal moet word - egter met die belangrike eis dat die blik gerig sal bly op die eintlike sin van die Ou Testament as getuienis van Jesus Christus.

Die aangehaalde uitspraak van die Heidelbergse Kategismus bring ernstige probleme aan die orde, probleme wat in die afgelope vier dekades veel besinning maar weinig klaarheid gebring het. Ten opsigte van die eenheid van die Skrif is daar eerstens die feitelike toestand dat daar twee teologiese vakwetenskappe, dié van die Ou en Nuwe Testament, bestaan wat elk in 'n byna afgeslote ruimte arbei sonder voldoende wedersysde aanraking en begrip. Verder die nog steeds florerende godsdienshistoriese omknelling wat elke testament as 'n godsdiensoorkonde beskou met hoofsaaklik historiese waarde. Derdens ook nog die klem wat in sommige kringe gelê word op die polariteit tussen Ou en Nuwe Testament, sodat Christus en Paulus hoofsaaklik gesien word as figure wat die Ou Testamentiese uitsprake korrigeer en 'n totaal nuwe godsdiens in die plek van die oorgelewerde stel. Ten opsigte van die voorlopigheid van die Ou Testa' ment as getuienisdokument is daar nog die berusting by ' $\mathrm{n}$ teologie van die Ou Testament as die finale produk van die Ou Testamentiese wetenskapsbeoefening. Dit is inderdaad ' $n$ vraag of daar nog sprake kan wees van 'n teologie wat nie van die hele Skrif uitgaan nie.

Dit is egter veral ten opsigte van die historiese gang van die evangelie wat ' $n$ lewendige diskussie ontstaan het. Die probleemkompleks in hierdie verband kan aangedui word met die woorde geskiedenis, geskiedskrywing, heilsgeskiedenis. Dit betref eerstens die waardering van die Ou Testament as boekversameling. Volg ons die literatuurhistoriese metode soos deur Gunkel ontwerp, vind ons onder die kleinste literêre eenhede naas baie ander vorme ook die historiese verhaal waarin die samehang van gebeure duidelik gesien en beskryf word. Tereg word beweer dat Israel die geskiedskrywing ondek het. Dit geld ook van groter literêre eenhede waarin 'n verskeidenheid literatuurvorme aangewend word in 'n samehangende geheel. Algemeen word aanvaar dat hierdie historiese bewussyn van Israel in sy Godsgedagte gegrond is. Die sekerheid dat Jahwe 'n lewende God is wat in die gang van Sy skepping ingryp en Wie se handeling in 
die geskiedenis ervaar word, is die fondament van Israel se siening van die werklikheid. Pannenberg meen om 'n bepaalde skema in hierdie ge' skeidskrywing te ontdek, nl. dié van belofte en vervulling. ${ }^{3}$ ). God gee beloftes en vervul hulle. Geskiedenis is dan die gebeure wat die spanning tussen die belofte en die vervulling bewerk. Die horison van Israel se historiese bewussyn word steeds wyer en die gebeure verloop tussen belofte en vervulling steeds omvattender. Hy verwys na die verhaal van die troonopvolging van Dawid as die eerste omvattende geskiedeniskonseprie van hierdie aard. Die verhaal begin met die belofte aan Dawid van die voortduur van sy dinastie (II Sam 7) en eindig met die vervulling deur Salomo se troonsbestyging (I Kon. 2). Hier is dit net die belofte wat die verloop van die geskiedenis beheer; in die deuternomistiese geskiedenis. werk tree egter 'n tweede element naas die belofte wat die uitkoms van die geskiedenis bepaal, nl. die sonde. Met die apokaliptiek word die geskiedenis dan op sy wydste uitgebrei tot die ganse verloop tussen skepp.ng en wêreldeinde. Daarmee is die vervulling nie meer binne-historiese nie maar is dit die einde van die wêreldgeskiedenis, terwyl 'n ewige verkiesing aan die geskiedenis voorafgaan en 'n ewige wet alle wêreldgeskiedenis fundeer. Geskiedenis is dan die werklikheid in sy totaliteit.

Terwyl daar met hierdie konsepsie van Pannenberg weinig fout te vind is, moet die opmerking tog gemaak word dat hy sy visie grond op 'n bepaalde histories-kritiese konstruksie, nl. die uitskeiding van eenhede soos die Jahwistiese en Deuteronomistiese geskiedeniswerke wat in die hu:dige gestalte van die Ou Testament nie herkenbaar is sonder die metodiek van die historisme nie. Hierdie opmerking voer al dadelik na die probleem van die geskiedenis. Om te kan voldoen aan die eise van die moderne geskied. skrywing soos dit sinds die Aufklärung beoefen is, moet die Ou Testamen. tiese stof ' $n$ radikale skommeling ondergaan. Dokumente en oorleweringe moet gewaardeer word na die maatstaf van onderlinge ooreenstemming en historiese betroubaarheid, seleksie van die kousaalwerkende gebeure tussen die toevallige uit moet plaasvind. Dan verskyn die geskiedenis, hetsy van die volk, die instellinge of die godsdiens, as 'n totaal nuwe ontwerp wat nie naastenby kongruent is aan die voorhande gestalte van die stof nie. Die radikale benadering van die historisme is in groot mate getemper deur die oorleweringshistoriese metode, wat nuwe lig gewerp het op die ontstaan van die Ou Testamentiese boeke en meer waardering gebring het vir voorheen minderwaardig-geagte materiaal. Ook het die besef geleidelik ontstaan dat die Ou Testamentiese geskiedskrywing gewaardeer moet word na die maatstaf van die besondere aard van die geskiedenis wat dit wil beskrywe. Dit is op hierdie besondere aard van die Ou Testamentiese geskiedskrywing wat Pannenberg in sy artikel die

3) Wolfhart Pannenberg, Heilsgeschehen und Geschichte, in Probleme

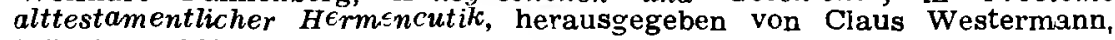
München 1960. 
lig wil laat val. Die Ou Testament is nl. 'n ,geskiedenisboek. Dit stel 'n deur Gods Woord gewerkte geskiedenis daar, van die wêreldskepping af tot by die koms van die Seun van die mens", in die woorde van von Rad. Pannenberg wil die samehang tussen Ou en Nuwe Testament dan ook sien in die gemeenskaplike bewussyn van die geskiedenis wat die eskatologiese gemeente van Jesus Christus met die ou Israel verbind deur die skakel van belofte en vervulling. Daarmee stel Pannenberg homself teenoor Bultman, wat met die skema profesie-vervulling werk en wat ook die geskiedenis neem as die verbindende element van die Ou Testament na die Nuwe toe. Maar vir Bultman is die Ou TestamentiesJoodse geskiedenis 'n profesie van die geskiedenis wat in die Nuwe Testament vervul is in negatiewe sin. Die Ou Testamentiese geskiedenis vertoon 'n innerlike teenspraak. Die ideë van die Verbond van God, die Koningsheerskappy van God en van die Godsvolk blyk onrealiseerbaar te wees. Daarom misluk die geskiedenis. En juis hierdie mislukking is die belofte. Die vervulling kan nie as produk van die historiese ontwikkeling gesien word nie, want die enigste waarop die geskiedenis uitloop is die mislukking. En daarmee sou dit op 'n end gewees het as God nie in Christus 'n nuwe aanvang gemakk het nie, 'n ,nuwe skepping" in eskatologiese sin.

Ek meen dat ook by Bultmann die vraag gestel kan word of die ge skiedenis wat op 'n ,scheitern" uitloop, nie weereens die produk is van 'n bepaalde konstruksie nie. Alte seker staan ons met die na-eksiliese gemeente soos uit Esra-Nehemia blyk, by die asse en die murasies van 'n volk se historiese gang. Maar is die geskiedenis van Israel die enigste element wat vra na die vervulling in die Nuwe Testamentiese heilsgebeure? Ongeveer in dieselfde tyd word die profetewoorde uitgespreek en versamel wat tans in Jes. 40-55 staan, en soms aangedui word as die woorde van die evangelie van die Ou Testament. Staan ons met Deuterojesaja ook by 'n „scheitern der Geschichte"? Vriezen sien 'n geleidelike geestelike gees' telike ontwikkeling van Moses na Deuterojesaja, „de laatste grote profeet, in wie de kennis van de openbaring Gods werd verdiept en verbreed, bij wie Jesus Christus dan ook dadelijk aansluit, en op wie Paulus in zijn brieven steeds opnieuw teruggaat". ${ }^{4}$ ). Ons keer dus terug na die formulering van von Rad, "'n deur Gods Woord gewerkte geskiedenis" wat soms in skrille teenstelling staan met wat die profane geskiedskrywing as die feitelike toestand sou aanvaar. Om hierdie probleem te omseil, word die term ,heilsgeskiedenis" soms aangewend as interpretament vir die geskiede. nis van die handelinge van God met die mense en die wêreld soos dit in die Ou Testamentiese literatuur neerslag gevind het. Omdat die begrip „,heilsgeskiedenis" egter 'n historiese belasting saamdra vanuit die heils' historiese skool wat met Hofmann sy hoogtepunt bereik het, en sterk onder

4) Th. C. Vriezen, Hoofdlijnen der Theologie van het Oude Testament, p. 29. 
die invloed van 'n bepaalde filosofiese visie gestaan het, word die begrip liewer afgewys.

Die probleem is dus nie dié van die samehang of nie tussen die twee testamente nie, maar wel wat die aard van hierdie samehang is. Lê hierdie samehang in die karakter van die openbaring as geskiedenis van die dábár van God wat tegelyk woord en gebeurtenis is en wat steeds 'n geweldige spanning meebring tussen die Openbaarder en dié wat die open. baring ontvang?. Is daar 'n eenheid van geestelike ontwikkeling van Abraham af tot op Christus soos uit Heb. 1:1 afgelei kan word? Omspan die skema belofte-vervulling, positief en negatief, die probleem?. Is die tipologie ' $n$ afdoende antwoord? Elkeen van die dusver voorgestelde antwoorde op hierdie probleem moet afgewys word as dit pretendeer om om enigste en afdoende antwoord te wees. Almal saam voorsien miskien wel 'n antwoord, hoewel nie voldoende nie. Watter maatstaf kan dan geld wanneer die kerk Christus wil rerkondig uit die evangelie in sy voorlopige sowel as in sy vervulde gestalte? Deurdat von Rad die klem heeltemal op die geskiedeniswerkende Woord van God laat val, kan hy die tipologie beoefen sonder om te verval tot allegoriese, bowe-historiese heilsbeelde. „Die tipologiese verklaring het egter net met die getuienis van die goddelike gebeure te doen en nie met die ooreenstemming van historiese, kultuurhistoriese of argeologiese besonderhede wat die Ou en Nuwe Testament gemeen het nie". ${ }^{5}$ ) Dit wil sê die aandag word steeds bepaal by die situasie waarin die Godswoord gebeur en gebeure werk. In die geval van die gebeure rondom die vrou van Hosea, die profeet, sal dit dus nóg die hoer nóg die persoon van die profeet wees wat die brug slaan na Christus toe, maar wel die ongure situasie waarin die Godswoord tot die profeet kom en vanwaaruit hy oordeel en verlossing moet aankondig -- die inkarnasie en knegskap geprefigureer.

Ook die skema van die ,geestelike ontwikkeling" tussen die ou en nuwe bedeling, of die liniêre aansluiting van die Nuwe by die Ou Testament, is in sommige gevalle bruikbaar. Dit kan geillustreer word uit die tradisio, nele kerklike hantering van Jes. 53, waarvan die woorde en situasie so direk op Christus betrek kan word en ook deur Homself betrek word: dat die invoering van ' $n$ bepaalde metodiek om die verband tussen die Kneg en Christus te toon, 'n onnodige omweg lyk.

Die skema belofte, vervulling berus enersyds op die Nuwe Testamentiese getuienis wat herhaaldelik voorkom, nl. die doelbewuste aanpassing van die optrede en lydensweg van Christus ,,sodat die Skrif vervul sou word", andersyds op die karakter van die Ou Testament as getuienis wat verhuld is ,onder die bedekking wat in Christus vernietig word",

¡) Aanhaling by Hans-Joachim Kraus, Geschichte der historisch-kritischer Erforschung des alten Testaments", p. 436. 
en dus voorlopig is. Hieronder kan ook Bultmann se „scheitern der Geschichte" geldigheid verkry, omdat die mislukking van alle menslike bemoeienis om God, die afsny van elke weg van benede na bo, net Gods weg van bo na benede ooplaat.

So is meer visies op die samehang tussen Ou en Nuwe Testament te wettig. Dink bv. aan Calvyn se visie van die tweede bedelinge, Luther se polariteit Wet-Evangelie. Trcuens, daar is net een maatstaf wat steeds aangelê kan en moet word om die geldigheid van die uitleg van die Ou Testamentiese Godsgetuienis te toets, nl. of Christus gestel word in die speerpunt van die Ou Testamentiese Godsgetuienis. Elke uitleg wat by Hom verbygaan sal deur die kerk afgewys moet word. Origens sal aan die prediker die vryheid gelaat moet word om, met wetenskaplike verantwoordelikheid en geloof sgehoorsaamheid tegelyk, die samehang Ou-Nuwe Testament te orden na geliewe - „solank Christus maar verkondig word”.

Rustenburg.

J. P. OBERHOLZER. 